\title{
The social and historical situation in the nineteenth-century Kazakhstan and the anti-colonial trend in Kazakh literature
}

\author{
Alya Akimkizi Oskembay, Bakytzhan Bekenovna Kelgembaeva, Baurzhan \\ Amangeldyevich Yerdembekov
}

\author{
Sarsen Amanzholov East Kazakhstan state university, Ust-Kamenogorsk, Kazakhstan. \\ Email: aoskembay@bk.ru
}

Received May 03, 2018; Revised September 09, 2018: Accepted October 27, 2018; Published November 02, 2018.

\begin{abstract}
:
The paper features a brief review of the history of Russia's colonization of Kazakhstan in the nineteenth century. During this period, Russia was engaged in colonial activities in Asia. After conquering the Kazakh lands, Russia launched a policy of russification and started to force a new sociopolitical model upon the Kazakhs. The research investigates the status of the Kazakh population in Russia and that of the people who were forced to move to China. The research also reviews the attempts of Kazakhs to regain their independence through rebellions, which were suppressed violently by imperial armed forces. The authors analyzed the works of East Kazakhstani poets in the context of the sociocultural processes of that age. The poetic works best reflect the mood of the nation and its attitude to the new policy. The poems of Arimzhan Zhanuzakuli, Argynbek Apashbayuli, and Nogaybay Suleymenuli discover and contemplate the themes that reflect the political and social controversies of the age of economic, political, and cultural expansion into the country (the theme of disappointment with the past and fear of the future) and unite the poets into the "times of tribulation" literary trend. The works of the "times of tribulation" poets gave impetus to the national rebirth of Kazakhs and the return of independence and the possibility to choose their own policy. Due to the subjects addressed in their works, many poets were subject to purges. Nowadays, the Kazakhs have their own independent state of Kazakhstan, which became possible thanks to the national idea that was formed in the works of nineteenth-century poets.
\end{abstract}

Keywords: colonialization of Kazakhstan, "times of tribulation" literary trend, social lyric poetry, direct nomination.

\section{Introduction}

Nineteenth-century European countries carried out an active colonial policy. Vast lands in Africa and Asia were conquered as a result of this policy (Furnivall, 2014). One of the largest colonial empires was Russia, which ran an active colonial policy in Asia (Kazimov, Novruzov, \& Veliyeva, 2016), under which the Kazakh lands were conquered.

According to K. Marx's colonization theory and other historical and philosophical schools, the submission and exploitation of the native population are central to the study of colonialization (Landow, 2002). The main attribute of colonialization is the imposition of power

(C) AesthetixMS 2018. This Open Access article is published under a Creative Commons Attribution Non-Commercial 4.0 International License (http://creativecommons.org/licenses/by-nc/4.0/), which permits non-commercial re-use, distribution, and reproduction in any medium, provided the original work is properly cited. For citation use the DOI. For commercial re-use, please contact editor@rupkatha.com. 
onto the exterritorial community by a group of people, which is logically based on political submission, economic exploitation, and cultural domination (Hind \& Levering, 1984).

Social and humanities studies that were conducted in the past decades were focused on reconsidering the process of colonialization and its effect on the sociocultural aspect of the formation of an ethnic group. Several studies are devoted to colonialism and the results of the total exploitation of conquered territories by colonial powers (Felix, 2016; Loomba, 2005; Zhussupov et al., 2014).

The purpose of this research is to study the peculiarities and consequences of the expansion of the Russian Empire for the historical fate of Kazakhstan and the reflection of the tragic status of the country's native people in the legacy of East Kazakhstani poets.

The repressive regime of the Russian Empire for centuries purposefully conquered territories and nations and ran a hardline colonial policy with respect to the latter, which resulted in the elimination of millions of people, collapse of the social foundations of ethnic groups, their traditions, and spiritual culture (Kappeler, 2014; Pavlenko, 2013).

In the first half of the nineteenth century, the Russian Empire launched a campaign of mass conquering of Kazakh lands. The imperial government conducted a series of reforms to accelerate the colonialization process. On June 22, 1822, the Russian emperor issued the Decree "On Institutions for the Siberian Governorate", "Decree on Administering "Ingenious Dwellers"”, "Decree on Administering Kyrgyz-Kaisaks", and other pieces of legislation. In the conquered territories, the colonial power transformed the administrative structure (abolished the khans' power, as well as traditional electoral and tax systems) and engaged in ethnic discrimination against the native people (Mishra, 2013; Penati, 2012).

Regional Prikazes and fortresses were built on Kazakh land; the amount of taxes collected from local dwellers grew; Kazakhs were forced to serve as sentries or caravan escort; Kazakhs were russified and baptized by force (McMillan, 2016).

The gradually growing economic pressure on the Kazakh people of the Bukey Horde caused an escalation of social and ethnic conflicts, which logically resulted in an outburst of armed conflicts. In 1836-1838, a peasant rebellion broke out in the Bukey Horde headed by Isatay Taymanov and Makhambet Utemisov. On July 12, 1838, the main group of rebels (500 men) clashed with the forces under the command of colonel Geke between the rivers Akbulak and Kiyl. The Russian emperor was afraid the Kishi Zhuze (Junior Horde) and Orta Zhuze (Middle Horde) could unite their rebellious forces, which is why he sent his entire force to suppress the rebellion in this area. The forces were unequal and the rebellion was suppressed; Isatay Taymanov died on the battlefield (Morrison, Veniukov, Bezobrazov, \& Hosking, 2012; Von Haxthausen, 2013).

Another attempt to restore the khans' power in 1837-1847 was made by rebels headed by Kenesary Kasymov. Kenesary Kasymov was elected khan in 1841. Kenesary Khan restored the traditional powerful state that spanned the entire Kazakh land up to Irtysh, Esil, and Ural, where the colonial power of the Russian Empire was established. Kenesary Kasymov, who showed exceptional courage in his fight against the colonial policy of Russia on the one hand and against the Khanate of Kokand on the other hand, died in battle with the Kyrgyz (Furnivall, 2014; Pavlenko, 2013).

The end of the annexation of Kazakh lands by Russia made significant changes to the imperial policy in respect of the Kazakh region. According to the 1868 "Provisional Regulation", the Kazakh land was declared state property of the Russian Empire and part of imperial Russia 
(Kappeler, 2014; Von Haxthausen, 2013). The Kazakhs were deprived of fertile land. Not having found a place in their own land, they were forced to resettle en masse. By the 189os, vast fallow lands had been explored and the Russian fiscal policy was in effect, which, however, did not take into account the interests of the local population, which turned the Kazakh nation into a victim of colonialization (Morrison et al., 2012).

The tragic worldview of a nation that was forced to live under oppression and ethnic discrimination was reflected in the legacy of the late-nineteenth-century Kazakh poets. The spiritual quest, active struggle, and ideas of liberation of Kazakhs were reflected in the poems of Arimzhan Zhanuzakuli, Argynbek Apashbayuli, and Nogaybay Suleymenuli, who were arbitrarily united into the "times of tribulation" literary trend.

The legacy of the "times of tribulation" Kazakh poets is understudied in Kazakh literary science and virtually unstudied in foreign literary science. It is possible to distinguish several most significant works, which highlight certain aspects of the subject and provide materials for followup studies, despite not covering the problem entirely (Ivanovsky, 1889; Zhussupov et al., 2014). However, since the studied period is notable for its dynamic changes, formation of new ideals, social groups, and literary trends that reflected the complex historical and sociopolitical realities of the age, and an in-depth study of the artistic synthesis of the spiritual world of the Kazakh nation in the works of "times of tribulation" poets, its investigation is of considerable scientific interest.

\section{Method}

The methodological and theoretical framework of the research includes a set of historical and philosophical principles: historicism, objectivism, dialectic unity of history and logic, comparative-historical, and historical-analytical methods. The general scientific methods that were used to characterize the critical epistemology of nineteenth-century Kazakh poets included abstraction and generalization.

One of the most important methods is the historicism principle, which allows examining poetic works with regard to the social and historical situation at the time. The objectivism principle allowed for a comprehensive analysis of critical attitudes in a specific historical process.

The subject matter at hand required an interdisciplinary approach and additional reference to philosophy, history, logic, psychology, and ethics.

\section{Data, Analysis, and Results}

The term "literary trend of the times of tribulation" was coined by Mukhtar Auezov, who wrote The History of Literature (1927) - the first work that generalized the achievements of Kazakh literature (Zhussupov et al., 2014). According to Auezov, the thematic dominant in the "times of tribulation" poetry was social and national motives. The poems of Dulat Babatayuli (poet, of East Kazakhstan descent), Shortanbay Kanayuli (poet, of South Kazakhstan descent), and Murat Monkeuli (poet, of West Kazakhstan descent) reflect the historical, social, public, and political conditions that the Kazakh nation found itself in (Zhussupov et al., 2014).

In 1881 , Russia and China signed a treaty that settled the issue regarding the border in the Ile region. Afraid of a rebellion of Muslims in China, which laid claim to the annexed territory, Russia occupied the Ile region, which was close to the Kazakh land, in 1871. After suppressing the 
rebellion in Xinjiang, China demanded that Russia return Ile. After continuous diplomatic negotiations between the two states, both parties signed the Petersburg Treaty on February 12, 1881. The people who lived in Ile territories were given the permission to choose their preferred place of resettlement within a year.

According to the Chinese-Russian treaty, the border of the Ile region started with the Pekin Mountain along Qorghas River and ran up to its influx into Ili River. It then ran along the riverhead in the Kozhat village in the modern Almaty Region and spanned the region up to Uzynkaratau. The incorrect demarcation of the border between Russia and China prevented free migration of Kazakhs to pastures and wintering. This caused a new demarcation of the RussianChinese border. The issue regarding the border near Zaisan and Kara-Irtysh was settled in favor of Russia. The borderline started with the Kuytin mountains on the Kara-Irtysh River bank and crossed the Saur Mountains.

The shifting borders between Russia and China, intensive social oppression, loss of fertile land, mass resettlement, and derogation of national dignity was widely reflected in the works of the folk poets of East Kazakhstan. In addition to Zhanak Sagyndykuli, Tubek Baykoshkaruli, and Dulat Babatayuli, who became beacons of the people's word, it is worth mentioning such poets as Nogaybay Suleymenuli, Argynbek Apashbayuli, and Arimzhan Zhanuzakuli. These authors are not widely known to the general Kazakh audience; however, they were popular poets of the Eastern region. By expressing their discontent to the center, they created true realistic poetry. Their works conveyed the main conceptual message of realism - the depiction of life in forms of life, which is why their attention was always focused on the urgent problems of their compatriots: alienation of territories, plundering of land, atrocities of the powers that be, bribery, human degradation under national discrimination, etc.

Changes in the established values in the traditional Kazakh society, transformation of the government system, and intensifying assimilation caused by colonialization brought the "times of tribulation" poets to the historical scene. They became famous as national public figures that cared about the status of the people.

Arimzhan Zhanuzakuli (1878-1946) is an outstanding poet of this trend. He was born near the foothills of Manyrak Mountain in the Tarbagatay District, East Kazakhstan Region; he passed away far away from his motherland, in Kulystay in China. Since 1992, his poems and epic songs have been published in several collections in Kazakhstan and China (Zhussupov et al., 2014).

Arimzhan's poems are a bitter cry caused by the tragedy of a single nation that was split in two by new borders and a longing for the motherland. The poet realistically depicts the tragedy of the Kazakh people caused by Russia's colonial policy:

In Manyrak and Tarbagatay,

The sunshine was so bright

An orphan could enjoy his day,

The lands were stunning quite

Alas, no luck and no way out,

The families broke, they did move out...

My poor humble people have drifted apart, 
Prostrate and weak, so hard to take heart.

The father was banished,

The son is in sorrow,

The junior brother is jailed on the morrow,

The senior brother's in tears... (Zhussupov et al., 2014)

The work is based on a conceptual antithesis: "the sunshine was so bright" - "prostrate and weak". The rhetorical exclamation emphasizes the emotional perception of the lyrical hero, who suffers from the realization of the total collapse of the foundation of his ethnos, the destruction of the patriarchal origins of the family "the father was banished" - "the son is in sorrow" - "the junior brother is jailed on the morrow" - "the senior brother's in tears".

The sacred images that are actualized in Arimzhan's poems create a vibrant picture of the world, in which the author's compatriots were forced to live:

The horse has been caught for the slaughter

The wise men are under inquest

While missing their land and their daughters

The elders are weak and depressed

Will they have inside them the power to seize

To kill this incurable horrid disease? (Zhussupov et al., 2014)

The image of a horse has a special meaning for nomadic people. For Kazakhs, a horse embodies power, agility, and passionate strength. Since the bond between equestrians and horses was considered mystical, close, and inseparable, the threat to the horse's life also meant a direct threat to the hero's power and deprived him of the possibility to resist adverse circumstances.

Eastern-Kazakhstani genealogical book expert Boshay Kitapbayev writes the following regarding the resettlement of the Naimans from their native land: "In the 186os, the imperial government set sights on the Altay highlands, its vast areas and animals. It seized the plains along the rivers Bukhtarma and Kara-Irtysh, the lands surrounding lakes Marka and Zaisan, and resettled the mountain dwellers - Naimans - from their native land and the pastures of their ancestors. The brothers, whose land has been taken away by the emperor, thousands of people, hundreds of families, resettled in China, Mongolia, and crossed the Altay Mountains with one question in mind - "What is to become of us?" They lost their cattle and horses, many of them returned and found refuge in the lands along the Kos-Agash and Shuy rivers (land along the Russian border - authors) (Berdikhojayeva, 2016). The resettlement of other Naiman families from their ancestors' lands was preserved in folk memory as "Kozhambet Resettler", "Utey Resettler", and "Samay Resettler" (core families of the Naiman tribe, who found refuge in the southwestern part of East Kazakhstan - authors). Succumbing to Russian oppression, Arimzhan and his tribesmen also left their motherland:

The folks of Saty tribe - we left on the morn (we moved to China)

Will our dearest kindred be sad? Will they mourn?

"The cattle has fallen, it's lost in the flow" 
It hurts to hear gloat in the words of your foe... (Zhussupov et al., 2014)

Arimzhan also describes the life of migrants in China:

The ones who came to China were forced to just obey

The rawhide bridle has worn down

The iron shackles brought dismay (Zhussupov et al., 2014).

The alienation of fertile land, the deteriorating wellbeing, and the hopeless situation the people found themselves in moved the poet. The poet listed each ravine and valley, the rivers and lakes, the hills and mountains in his native land:

We miss the Shorga and its plot

The land supports you and your lot.

Maily, Zhayir, we want you back

Nothing compares to Manyrak.

Will people get to reunite?

I miss the wind, so sweet and light

I miss the silver gliding wake

Of gentle sacred Zhaisan lake... (Zhussupov et al., 2014).

The main theme of the poetry is the word "miss" - a direct nomination of the lyrical character's mental state.

Arimzhan Zhanuzakuli depicted the age he lived in skillfully and as objectively as possible. His stance was based on his personal experience and the realities that resulted from the events that took place in the society of that time. As an improviser-poet, Arimzhan Zhanuzakuli spent his entire life with his people, experienced all the hardships together with the people, and sought ways to solve these problems.

Another narrator of that age is Argynbek Apashbayuli. He was born in 1883 in Akaral village, Zaisan District, today's East Kazakhstan Region. He passed away in 1946 in the Altay region in China. He came from the Dortuil family, Naiman tribe. His genealogy is as follows: Argynbek - Apashbay - Shona - Kempir - Baykozha - Elaman - Kortyk - Kudakeldi (Zhussupov et al., 2014). A master of oral folk art traditions and oriental literature, Argynbek was one of the most educated men of his age; he was proficient in Arabic and Persian. In 1894, he suddenly moved with the resettled auls to the Altay region of China. The trends that dominated several of his poems ("Argynbek Picked Up a Quill”, "The Land is the Mother of Man", "My Family - the Kazakhs", "Geographical Legend", “The Times Have Changed", etc.) are the grief of the times, the longing for the motherland, and the call for the fight against colonialization.

For instance, the "My Family - the Kazakhs" poem has a protest theme, which is realized through antithesis - "foreign people" - "our people", "sun" - "darkness". Binary opposition, which is traditional for oriental poetry, creates an expressive narrative context:

Foreign people have the dawn, as well as the sun

Our people live in darkness, nothing can be done 
As I take the quill and write, me - the humble scribe,

All the wonders of the soul, ready to describe (Zhussupov et al., 2014).

Argynbek Apashbayuli's poems are honest, sincere, and emotional. They are dominated by self-intonation. The poet describes the mysteries of his heart and his longing for the motherland, he expresses the pain of an entire generation that was forced to leave its native land:

Lo, the pastures of Altay have become confined

Cattle's few and far between, barely there to find

Once we roamed these endless lands, which we so admired

Now we've lost our promised land, now my soul is tired (Zhussupov et al., 2014).

In the author's opinion, the future of the people is unclear, which is why the lyrical hero reminisces of his past and dreams of going back. At the conceptual and intonational level, these poems are in tune with the works of Shortanbay Kanayuli, Dulat Babatayuli, and Murat Monkeuli.

The unpunished aggressive colonialization carried out by the Russian Empire was reflected in the poems of Murat Monkeuli:

So they took away the Volga, they shackled our feet

Took away Oyil, as well, we suffered defeat

Then they took away Ural, took us by the throat

They did anything they wanted, with unending gloat (Zhussupov et al., 2014).

Another prominent figure of that age was Nogaybay Suleymenuli Kulibay (1831-1914), who was born near Zaisan Lake in the East Kazakhstan Region and became known for his poetic giftedness. The creativity of the talented poet was not hindered by his congenital blindness. His family is Karakerey - Zholymbet (Ivanovsky, 1889).

The works of Nogaybay Suleymenuli Kulibay first drew attention of Russian ethnographer A. Ivanovsky, who researched said works. In 1889, in the third issue of the Ethnographic Digest journal, he published an article titled "Nogaybay - the Narrator of the Kazakh People" (Ivanovsky, 1889).

In this article, the Russian scholar, who was fascinated by the poetic and songwriting works of Nogaybay, wrote the following: "How can one possibly spend time among the Kyrgyz and not hear the name of their famous poet Nogaybay mentioned? His fame is as widespread as is the Kyrgyz land vast. As soon as you cross the Irtysh, you will find this name mentioned in every nook. You can cross the vast hollows of Zaisan and Shieli, you can cross the Tuyetas or Sarytau passes, you can descend into the deepest ravines of the Altay, Saur or Tarbagatay mountains, where man can hardly pass, you can even ascend to the heavenly world in your thoughts - you will hear this poet mentioned everywhere. His songs ring of spiritual hardships, protest, and many a grief and sorrow of his people" (Ivanovsky, 1889).

The ethnographer collected and published the works of the poet that were preserved in folk memory, such as "Lofty Mountains Host Vast Treasures", "If I Were Almighty", and "To the Volost Shaken" (Ivanovsky, 1889). Nogabay's legacy that stood the test of time shows the poetic power, the source whereof is folklore:

Treasure is the soul's delight 


\section{Nation are your respite}

Should death come with its eternal strife,

For my people I will sacrifice my life (Ivanovsky, 1889).

The poet's worldview definitely affects the artistic image he creates, since the inner world of the lyrical hero is revealed primarily through the mental state and his experience of specific circumstances. The romantically inspired hero strives to ascend, sacrifice himself, and realize the universal humanity ideas - to give one's life for one's people.

A. Ivanovsky immediately identified that Nogaybay was talented and different from other poets, who tried to please the local volost beys and sold their work. The ethnographer wrote in fascination: "I've seen many a Kazakh singer and poet with khans and sultans as their patrons <...> But he turned out to be nothing like them, totally different" (Ivanovsky, 1889).

The lyrical hero of many Nogaybay's poems emphasizes the mission of his life and describes his priorities in life:

My conscience helps me write my song,

My blood is boiling, heart beats strong.

My words are not to please the throng

To no one else do they belong (Ivanovsky, 1889).

The epithets "boiling blood" and "beating heart" make the impression of the hero as a vivid personality, who is ready to resist and fight the hardships of life and who reflects the spirit of the ethnos.

In the poem "If I Were Almighty", similar to Makhambet's poem, the author praises the "Great Dream":

I would be the sun and I'd shine through the day,

I'd move all the dark clouds right out of my away,

I'd uproot all meanness, no trace would remain,

I'd plant seeds of justice throughout the domain.

I'd fly like a bird on wings far and wide

I'd have faith in honesty so dignified

I would quench the thirst of the people in need

By bringing the water on my wings with speed.

I would be the rain and shower with light

I would be a star, so shiny and bright

I'd know where to look for the justice we've lost

I'd reach it, I know it, no matter the cost... 
If I were almighty, all powers combined

I'd make people equal with no one behind

Without any trickery, stealth or deception

I'd give people wealth without misconception... (Ivanovsky, 1889).

Modern literary science tends to reconsider the term "romanticism", expand the respective discourse, and assume the existence of "romanticism beyond romanticism". For instance, K. Ankudinov argues against limiting the "romanticism" concept to a specific age (Ankudinov, 2013). The lyrical hero of this poetry generally fits the romantic canon - he is a vivid personality that realizes the flawed nature of reality, wishes to transform it, to fight, and to sacrifice. The anthropomorphic images of the sun, rain, and stars create a special artistic world, which is typical for the arbitrary-poetic perception of romanticists.

The "would be" anaphora creates a vibrant rhythm-euphonic structure of the poem on the one hand and makes the conceptual plane more expressive by emphasizing the lyrical hero's realization of the need for changes on the other hand.

\section{Discussion}

In addition to his poetic legacy, Nogaybay Suleymenuli Kulibay was famous for participating in song competitions against such poets as Zylikha and Aytbala. This was mentioned by Mukhtar Auezov, A. Bukeykhanov, and others (Toktagazin, Adilbekova, Ussen, \& Tastan, 2016). The search for his words that were preserved among the people, their collection and generalization are a challenge for the current generation and a task for future generations.

Although the poems that stood the test of time do not explicitly mention the colonial policy of the Russian Empire and the status of the Kazakh people, they clearly express the discontent of the poets over the social realities, their aspiration to justice, romantic pathos, and the desire to recreate the "world of dreams" (Zhussupov et al., 2014).

The works of nineteenth-century Kazakh poets feature a common notion of the need for independence and national self-identification (Berdikhojayeva, 2016). However, the strict control of the imperial government at the time made such aspirations impossible, which is evidenced by multiple rebellions that were suppressed by governmental forces. Due to the suppression of the people's will, many Kazakhs were exiled. These events were reflected in the works of poets, who praised the participants of rebellions as national heroes, further stressing the national distinctiveness of Kazakhs.

The intellectuals have always been the driving force of the nation (Hind \& Levering, 1984). In Kazakhstan, this is especially applicable to poets, who emphasized the socio-political problems of Kazakh lands during the colonial period (Penati, 2012).

The main enlightening activity of the "times of tribulation" poets was as follows: culture

- Description of the socioeconomic problems related to the enforcement of a new

- Description of the difficulties related to the forced resettlement to other countries, such as Mongolia and China

- $\quad$ Call for national unity and struggle against the colonial policy. 
In their works, the poets used artistic images from the Kazakh culture to further emphasize the emotional constituent of the poem.

The works dating back to the "times of tribulation" largely set the vector for the development of Kazakh culture. Poets of that time made a considerable contribution to the development of the national idea.

\section{Conclusion}

The works of the "times of tribulation" poets addressed the imperial policy of Russia on the colonialization of Kazakh lands in the nineteenth century. The poems of Arimzhan Zhanuzakuli, Argynbek Apashbayuli, and Nogaybay Suleymenuli reflect the attitude of their people, who were forced to leave their native land and violate the usual order of things and their customs and who lost their identity. The conceptual and intonational dominant in these poems was criticism of the colonial policy of the empire, disappointment and loss of hope of changes. Several works feature a theme that idealizes the past, which is traditional for romanticism poetry. As an integral part of the national world, the "times of tribulation" poets knew the sore points and unsolved problems of their ethnos. Therefore, the theme of patriotic devotion and sacrifice is one of the main ones in their work, while the lyrical heroes of poems realize their distinction and act as champions or bearers of higher knowledge, castigators of evil and moral judges.

The poets' correct understanding of the mysteries of that age and their fair assessment remains relevant from the axiological, ideological, and thematic perspective. Said poets made a special contribution to the artistic and esthetic value of the word, the artistic pattern, and the beauty of poetry. Therefore, the works of prominent "times of tribulation" artists holds a special place in the history of national literature.

\section{References}

Ankudinov, K. N. (2013). The content of the methodological concept of "romanticism beyond romanticism" revisited Adygea State University. Series 2: Philology and History of Art.

Berdikhojayeva, L. (2016). Postcolonial readings of Oralkhan Bókei's works : Dissertation - Nazarbayev University, School of Humanities and Social Sciences.

Felix, S. M. C. (2016). Fostering criticality within neoliberal higher education: a critical action research study with first year studentsin Kazakhstan.

Furnivall, J. S. (2014). Colonial policy and practice : a comparative study of Burma and Netherlands India.

Hind, R. J., \& Levering, J. (1984). The Internal Colonial Concept. Comparative Studies in Society and History, 26(3), 543. http://doi.org/10.1017/Soo10417500011130

Ivanovsky, A. A. (1889). The national Kyrgyz singer and poet - Nogaybay. Ethnographic Digest., (3), 92-101.

Kappeler, A. (2014). The Russian Empire : a Multiethnic History.

Kazimov, K. S., Novruzov, R. M., \& Veliyeva, \& Z. A. (2016). The Journey of Nikolaj Tikhonov along the Caucasus and the Representation of its Customs and Traditions in his Works. IEJME-Mathematics Education, 11(6), 1557-1562.

Landow, G. P. (2002). The Metaphorical Use of Colonialism and Related Terms. — «Political Discource — Theories of Colonialism and Postcolonialism». - Available:

http://www.postcolonialweb.org/poldiscourse/colony2.html - Accessed on: 16.10.2011.].

Loomba, A. (2005). Colonialism/postcolonialism. Routledge.

McMillan, M. E. (2016). The Russian Empire and the Arab World: Religion, Royalty, and the New Rome. In From the First World War to the Arab Spring (pp. 39-46). New York: Palgrave Macmillan US. 
http://doi.org/10.1057/9781137522023_5

Mishra, P. (2013). From the ruins of empire: the intellectuals who remade Asia.

Morrison, A., Veniukov, M. I., Bezobrazov, V. P., \& Hosking, G. (2012). Metropole, Colony, and Imperial Citizenship in the Russian Empire. Kritika: Explorations in Russian and Eurasian History, 13(2), 327364. http://doi.org/10.1353/kri.2012.0016

Pavlenko, A. (2013). Language Management in the Russian Empire, Soviet Union, and Post-Soviet Countries. Oxford University Press. http://doi.org/10.1093/oxfordhb/9780199744084.013.0032

Penati, B. (2012). Tsars, Cossacks, and Nomads. The formation of a borderland culture in Northern Kazakhstan in the eighteenth and nineteenth centuries. Central Asian Survey, 31(3), 375-377. http://doi.org/10.108o/02634937.2012.717437

Toktagazin, M. B., Adilbekova, L. M., Ussen, A. A., \& Tastan, R. A. N. (2016). Epistolary Literature and Journalism: Theoretical and Practical Aspects. International Journal of Environmental and Science Education, 11(13), 5833-5843.

Von Haxthausen, B. (2013). The Russian Empire: Its People, Institutions and Resources. Routledge.

Zhussupov, N. K., Kanapianov, K. N., Kurmanova, Z. K., Batkeeva, B. T., Baratova, M. N., \& Latypova, Z. H. (2014). Kazakh poetry of the XIX century: problem of its translation into other languages. Life Science Journal, 11(11s), 543-568. Retrieved from http://www.lifesciencesite.com 